\title{
ECOLOGICAL CHARACTERISTICS AND HABITAT PREFERENCES OF OSTRACODA (CRUSTACEA) WITH A NEW BISEXUAL POPULATION RECORD (MUĞLA, TURKEY)
}

\author{
AKDEMIR, D. ${ }^{1 *}$ - KÜLKÖYLÜOĞLU, O. ${ }^{2}-$ YAVUZATMACA, M. ${ }^{1}-$ TANYERI, M. $^{2}-$ GÜRER, M. $^{2}-$ \\ ALPER, A. ${ }^{3}-$ DERE, Ş. ${ }^{4}-$ ÇELEN, E. ${ }^{1}-$ YILMAZ, O. ${ }^{1}-$ ÖZCAN, G. ${ }^{1}$ \\ ${ }^{1}$ Institute for Geology and Mineralogy, University of Cologne, Zülpicher Str. 49a, 50674 \\ Cologne, Germany \\ ${ }^{2}$ Department of Biology, Faculty of Arts and Science, Bolu Abant İzzet Baysal University, 14030 \\ Bolu, Turkey \\ ${ }^{3}$ Department of Biology, Faculty of Arts and Science, Balıkesir University, 10440 Ballkesir, \\ Turkey \\ ${ }^{4}$ Department of Biology, Faculty of Arts and Science, Bursa Uludağ University, 16059 Bursa, \\ Turkey \\ *Corresponding author \\ e-mail:dakdemir@uni-koeln.de; phone: +49-221-470-5784; fax:+49-221-470-1663
}

(Received $17^{\text {th }}$ Sep 2019; accepted $8^{\text {th }}$ Jan 2020)

\begin{abstract}
In order to compare the ecological characteristics of non-marine ostracods with different reproductive modes, 68 sites including 11 different habitat types were examined in the province of Muğla during July of 2014. A total of 28 taxa were found and 11 of them were new reports for Muğla. Sexual populations of Psychrodromus olivaceus and P. fontinalis were encountered from the same sampling site. Males of the latter species were reported for the first time from Turkey. The female/male ratio of these species was higher at low altitudes while it was about the same at medium altitudes. Numbers of species in sexual and/or parthenogenetic populations with/without swimming setae and individuals in natural and artificial habitats did not show significant difference $(P>0.05)$. Troughs were described as the richest habitats for ostracods. The first two axes of Canonical Correspondence Analysis explained $66.2 \%$ of the relationships between species and environmental variables when the water temperature was the most effective factor on species composition $(P<0.01)$. Results suggest that type of reproductive modes did not show significant relationship with species distribution among different water bodies. Hence, it seems distribution of species is most probably affected by several biotic and abiotic factors.
\end{abstract}

Keywords: non-marine species, distribution, natural-artificial habitats, altitudes, swimming ability

\section{Introduction}

Although, freshwater habitats occupy only small parts of the Earth's surface with a ratio of $0.8 \%$, they host approximately $6 \%$ of species known in the world (Dudgeon et al., 2006). In this respect, freshwaters are considered to be one of the main sources of biological diversity on the Earth. However, these habitats are known to be affected at global (e.g. climate changes) and local (e.g. species invasion, habitat degradation, water pollution) scales by a variety of biotic and abiotic factors (Dudgeon et al., 2006). Thus, different kinds of habitat destruction lead to changes in species composition, their geographic distribution, and also cause a decrease in species diversity (Finlayson et al., 2013). However, some features of the organisms including (i) morphological characteristics (e.g., to occupy different ecological niches with different movement types (Wiens, 2011), (ii) phenotypic plasticity (e.g., fitting ability of the size and shape 
as a response to the changes in environmental conditions (Carbonel et al., 1988)), (iii) biological characteristics (e.g., to tolerate rapid or great environmental changes with different reproductive modes (Cohuo et al., 2015)), and (iv) ecological characteristics (e.g., to endure unpredictable environmental conditions with high ecological tolerance levels (Külköylüoğlu, 2004)) allow species to cope with the changes and elevate their survival chances in a variety of habitats. These biological and ecological features of the species also determine the degree of their distribution and abundance at spatiotemporal scale in relation to habitat conditions (Heino and Tolonen, 2018).

Ostracods, small bivalved crustaceans, are an important part of biological diversity in freshwater habitats with approximately 2330 extant species (Meisch et al., 2019). They can be fossilized due to their carapace (two valves) which consists of low Mg-calcite. The first record of fossil ostracods dates back to Early Ordovician (ca. $485 \mathrm{Ma}$ ), and thus ostracods are known as one of the oldest groups in microfauna (Williams et al., 2008). Besides, they have different reproductive modes of sexual, parthenogenetic (asexual) and/or mixed populations, and exhibit specific ecological requirements and species-specific tolerance levels. The different types of reproductive modes of the ostracods can be related to taxonomic and ecological features of particular species (Gülen, 1985a; Cohen and Morin, 1990; Martens et al., 2008) and may depend on geographical and/or ecological isolation (Mayr and Ashlock, 1991). All these features contribute to their widespread geographic distribution and high species diversity and also make them a particularly valuable group for a number of purposes in palaeo- and neoenvironmental studies. If the ostracod species' morphological features and ecological preferences are known, they can be used to estimate water quality conditions and rate of environmental changes (Wagner, 1964; Mezquita et al., 1999; Külköylüoğlu, 2004). In addition, the knowledge of the present-day distributional patterns of ostracods according to their reproductive modes in different region and/or environmental conditions can also be used as an informative marker for non-marine ostracods in the ecological sense.

Studies on ostracods in Turkey exhibited that distribution of both parthenogenetic and sexual populations were widespread throughout the country (Külköylüoğlu et al., 2015; Yavuzatmaca et al., 2017). Nevertheless, the distributional pattern and habitat preferences of species according to their reproductive modes have not been discussed and explained the Muğla province in the south-western part of Anatolia. Therefore, the main aim of the study is to investigate ecological preferences and distribution of species with different reproductive modes among the different aquatic bodies of the region.

\section{Materials and methods}

\section{Site description}

The province of Muğla, which is located on the south-west corner of Turkey, was chosen as a research area because of the possibility to find a variety of aquatic habitats and the lack of extensive studies on ostracods in this area. It represents typical Mediterranean climatic conditions where summers are very hot, long and dry, winters are cool and rainy. In total, 68 sites containing 11 habitat types (lake, reservoir, pond, pool, ditch, canal, creek, stream, spring water, trough, and waterfall) were randomly chosen from sea level to $1093 \mathrm{~m}$ of altitude between the 12 and 15 of July 2014 (Fig. 1). 


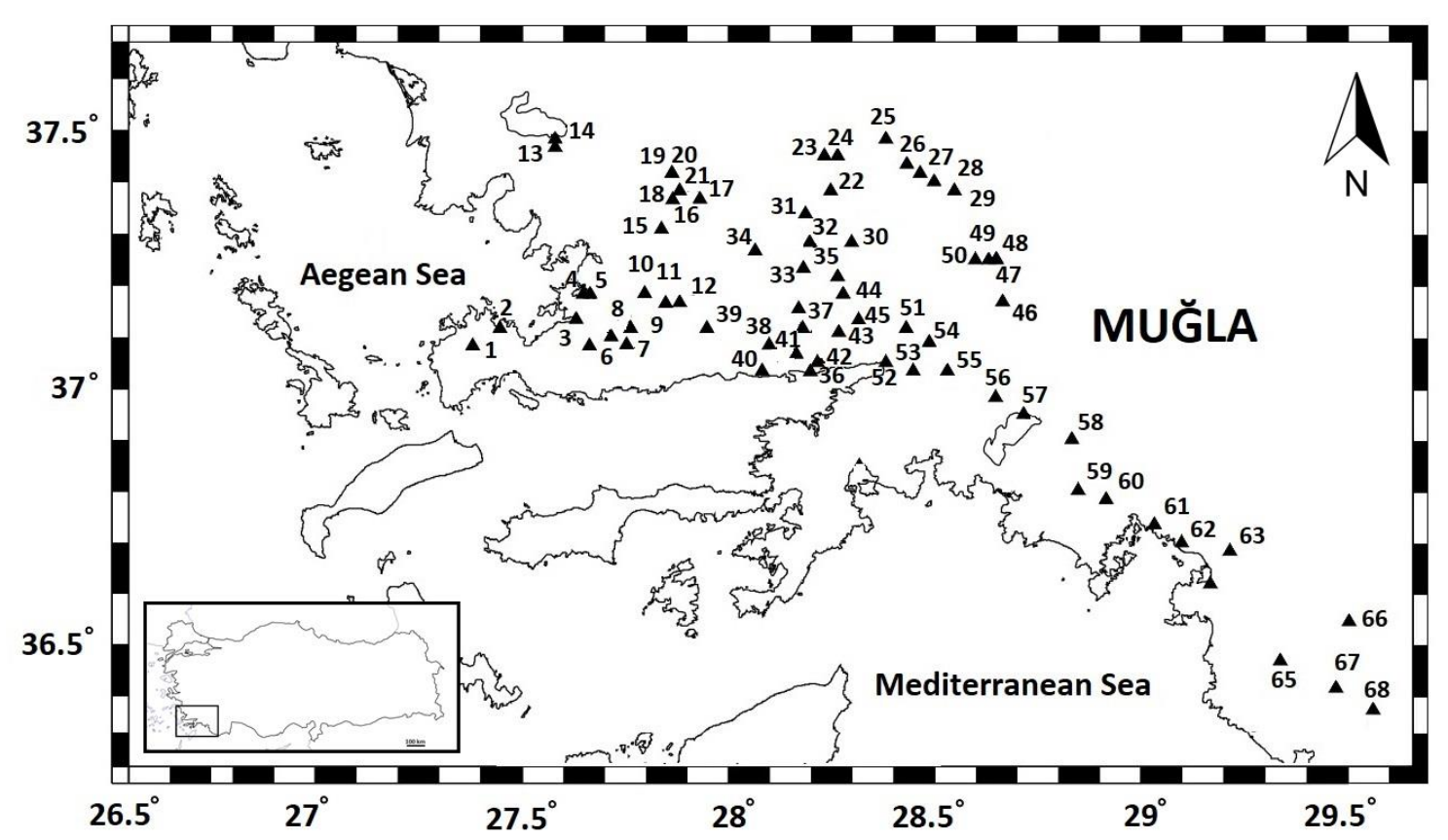

Figure 1. Distribution of the 68 sampling sites in the Muğla province

\section{Sampling and measurements}

Ostracod samples were collected with a standard sized hand net ( $200 \mu \mathrm{m}$ mesh size $)$ from the surface of sediments within an area of approximately $100 \mathrm{~cm}^{2}$ and a depth of up to $100 \mathrm{~cm}$. At each site, approximately $100 \mathrm{~g}$ of sediments were gathered and fixed with $70 \%$ ethanol in $250 \mathrm{ml}$ plastic containers in situ. In the laboratory, sediments including ostracods were washed and filtered through 4 standard sized sieves (1.00, $0.25,0.16,0.08 \mathrm{~mm}$ mesh size) under tap water and fixed in $70 \%$ ethanol for long term storage. Ostracod samples were sorted from sediments by using fine needles and Pasteur pipettes under a stereo microscope (Meiji-Techno). Soft body parts of ostracods were separated from the carapace and dissected in Lactophenol - Orange G solution. The carapace and valves were preserved in micropaleontological slides. Subsequently, species identification was carried out under a binocular microscope (Olympus-CX41) based on the dissected soft body parts and carapace structures by using the standard taxonomic works of Broodbaker and Danielopol (1982), Gonzalez Mozo et al. (1996), Meisch (2000) and Karanovic (2012). However, some species were identified at the genus-level because of damaged individuals, lack of soft body parts or only the presence of juveniles.

Environmental variables were measured in situ before sampling to avoid possible results of Pseudoreplication (Hurlbert, 1984). Dissolved oxygen (DO, $\mathrm{mg} \mathrm{L}^{-1}$ ), oxygen saturation $(\mathrm{S}, \%)$, electrical conductivity $\left(\mathrm{EC}, \mu \mathrm{S} \mathrm{cm}{ }^{-1}\right)$, water temperature $\left(\mathrm{Tw},{ }^{\circ} \mathrm{C}\right)$, salinity (Sal, ppt) and total dissolved solids (TDS, $\mathrm{mg} \mathrm{L}^{-1}$ ) of aquatic habitats were measured with a YSI professional plus device (Table Al in the Appendix). Geographical data (latitude, longitude, elevation) from each sampling site were determined with a Garmin GPS 45 XL (Fig. 1) while air temperature $\left(\mathrm{Ta},{ }^{\circ} \mathrm{C}\right)$, moisture (Moi, \%), wind (m $\mathrm{s}^{-1}$ ) and atmospheric pressure (Atm, $\mathrm{mmHg}$ ) were measured with a Testo 410-2 anemometer (Table Al in the Appendix). 
A $100 \mathrm{ml}$ of water was taken from each sampling site in plastic bottles and preserved in a container at $4{ }^{\circ} \mathrm{C}$ for the analyses of cations (sodium $\left(\mathrm{Na}^{+1}\right)$, potassium $\left(\mathrm{K}^{+1}\right)$, magnesium $\left(\mathrm{Mg}^{+2}\right)$, calcium $\left(\mathrm{Ca}^{+2}\right)$ ), and anions (fluoride $\left(\mathrm{F}^{-1}\right)$, chloride $\left(\mathrm{CI}^{-1}\right)$, sulphate $\left.\left(\mathrm{SO}_{4}^{-2}\right)\right)$. Analyses of these major ions were conducted in the laboratory of the Engineering Department of Bolu Abant İzzet Baysal University. The standard method no: 4110 using Ion Chromatography (Dionex 1100) was followed during the analyses. Also, sediment samples were collected from each site in eppendorf tubes for in/organic phosphate and total phosphate $\left(\mathrm{mg} \mathrm{kg}^{-1}\right)$ analyses. In the laboratory, sediment samples were dried in oven at $40{ }^{\circ} \mathrm{C}$ (at least $24 \mathrm{~h}$ ) and were subsequently analyzed according to Ruban et al. (1999) with a sequential extraction procedure (Table Al in the Appendix).

\section{Statistical analyses}

A Detrended Correspondence Analysis (DCA) was applied to confirm the suitability of the data for Canonical Correspondence Analysis (CCA) (ter Braak, 1986). The length of gradient in DCA was calculated as 3.64 referring the suitability of our data for CCA. CCA was performed to estimate most effective environmental variable(s) on species composition by using the CANOCO version 5 program (ter Braak and Šmilauer, 2012). The significance of the environmental variables used in CCA was tested by Monte Carlo permutation test (499 permutations). To eliminate possible multicollinearity, rare species were not used during the analyses. Shannon-Wiener (or Shannon, H') index values were calculated by using a Species Diversity and Richness 4 software (Seaby and Henderson, 2006) to determine the species diversity in different habitat types where the values of $\mathrm{H}^{\prime}$ (1.5 and 3.5) for ecological data suggest poor to rich diversity, respectively. In order to understand possible correlations among species and environmental variables measured here, Spearman Correlation Analyses were conducted in the SPSS program version 6.0. The C2 Software was used to measure ecological tolerance $\left(t_{k}\right)$ and optimum $\left(u_{k}\right)$ estimates of individual species along with Hill's coefficient (measure of effective number of occurrences) (Juggins, 2003). The chi-square test was used to determine whether there was a significant difference between the numbers/abundances of species in sexual and parthenogenetic populations with or without swimming setae in natural and artificial habitats. During the analyses, only adult individuals, occurred at least three or more times in different habitats, were used. The ostracod materials were deposited at the Limnology Laboratory of the Department of Biology, Bolu Abant İzzet Baysal University, Bolu, Turkey. Additional information about the sampling sites and species reported here can be available upon request from the authors.

\section{Results}

During this study, a total of 28 taxa (24 living and 4 sub-fossil) were reported among 11 habitat types while 11 of the living species (Candona weltneri, Psychrodromus fontinalis, Heterocypris barbara, Ilyocypris gibba, I. hartmanni, Limnocythere inopinata, Potamocypris arcuata, $P$. producta, $P$. unicaudata, $P$. villosa and Trajancypris leavis) were new for Muğla. The sexual population of $P$. fontinalis was found for the first time, while $P$. producta was recorded for the second time in Turkey.

The first two axes of the CCA explained about $66.2 \%$ of the relationship between 12 species and 5 environmental variables $(\mathrm{F}=2.9, P=0.04)$ (Table 1). According to CCA, 
the water temperature $(P=0.008, \mathrm{~F}=1.8)$ showed a significant effect on the ordination of species (Fig. 2). Except L. inopinata, four species (C. neglecta, I. bradyi and $P$. olivaceus, $P$. fontinalis) without (reduced or short) swimming setae on A2 were located on the left side of the CCA diagram, while species with swimming setae were situated on the right side of the diagram. However, one of the species with reduced swimming setae, Cyprideis torosa, was placed separately from other species on the CCA diagram (Fig. 2).

Table 1. Summary table of CCA. Test of significance of first axis, $F=2.9, P=0.04$; and all canonical axes, $F=1.5, P=0.028$.

\begin{tabular}{c|c|c|c|c|c}
\hline & Axis 1 & Axis 2 & Axis 3 & Axis 4 & Total inertia \\
\hline Eigenvalues & 0.483 & 0.186 & 0.173 & 0.116 & 7.699 \\
\hline Species-environment correlations & 0.763 & 0.464 & 0.514 & 0.413 & \\
\hline $\begin{array}{c}\text { Cumulative percentage variance of } \\
\text { species data }\end{array}$ & 6.3 & 8.7 & 10.9 & 12.4 & \\
\hline $\begin{array}{c}\text { Cumulative percentage variance of } \\
\text { species-environment relation }\end{array}$ & 47.8 & 66.2 & 83.3 & 94.8 & \\
\hline \multicolumn{6}{|c}{ Sum of all eigenvalues } \\
\cline { 2 - 6 } \\
\cline { 2 - 6 }
\end{tabular}

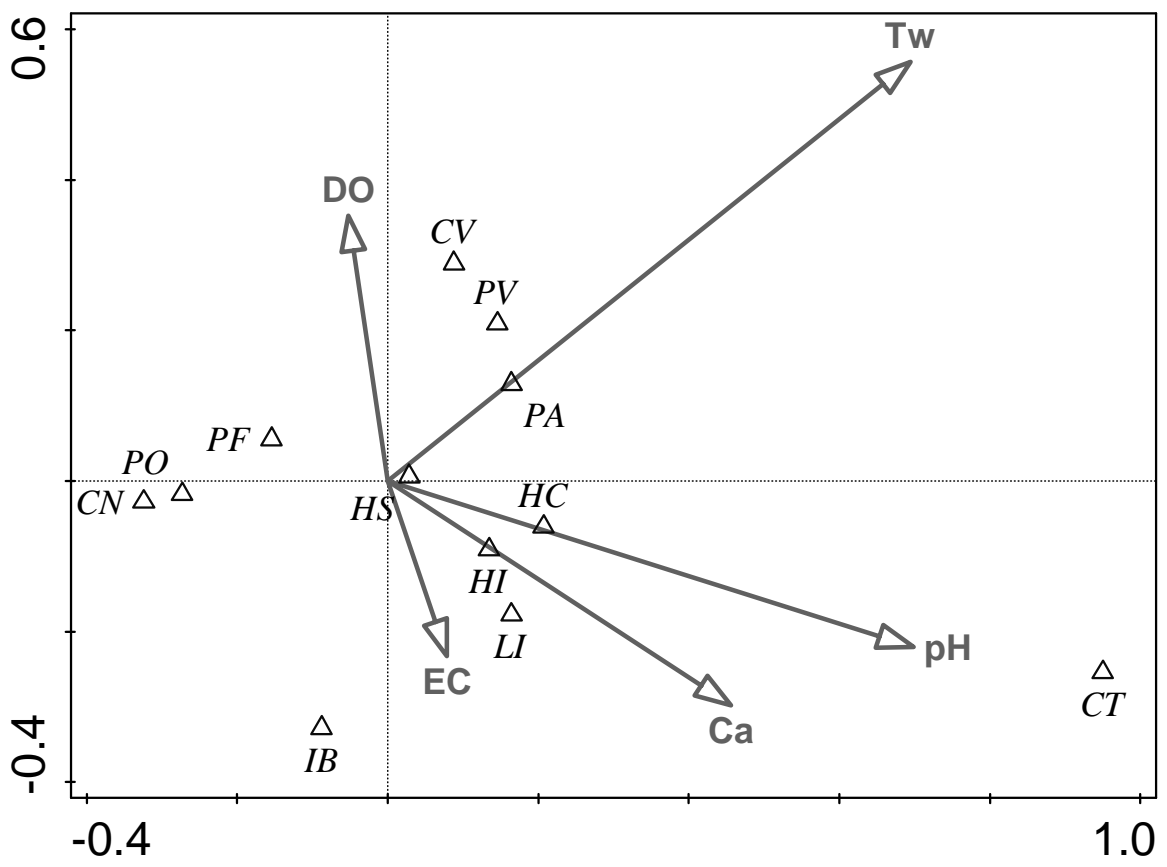

Figure 2. CCA diagram of five environmental variables (arrows) and 12 species (triangle). Abbreviations are given in Tables 4 and Al in the Appendix

According to the results of Spearman Correlation Analyses, H. salina showed negatively significant correlations with $P$. olivaceus and $P$. fontinalis while the correlation was positive with $I$. bradyi $(P<0.01)$. $P$. fontinalis exhibited a negative correlation with $L$. inopinata $(P<0.01)$. Among the species, $C$. torosa indicated strong 
and significant positive correlations with $\mathrm{Ca}^{+2}$ and $\mathrm{Mg}^{+2}$ values of the water bodies, when $P$. variegata showed negative correlation to $\mathrm{Ca}^{+2}$ and electrical conductivity $(P<0.01)$. Potamocypris variegata displayed low ecological tolerance values for dissolved oxygen, electrical conductivity, $\mathrm{Na}^{+}, \mathrm{Mg}^{+2}$, and $\mathrm{Ca}^{+2}$ when C. torosa showed the highest tolerances for total phosphates in the sediment, and several other major ions of the water bodies. Also, I. bradyi had the lowest tolerance levels for $\mathrm{pH}$ but the highest tolerances for conductivity and water temperature. Heterocypris salina displayed the highest tolerance levels for dissolved oxygen and $\mathrm{pH}$ (for more details see Table 2).

Table 2. Ecological tolerance $\left(t_{k}\right)$ and optimum $\left(u_{k}\right)$ levels of the 11 species occurred at least three times

\begin{tabular}{|c|c|c|c|c|c|c|c|c|c|c|c|c|c|c|c|}
\hline \multirow[b]{2}{*}{ Species } & \multirow{2}{*}{ Count } & \multirow{2}{*}{ Max } & \multirow{2}{*}{ N2 } & \multicolumn{2}{|c|}{ DO } & \multicolumn{2}{|c|}{ pH } & \multicolumn{2}{|c|}{ Tw } & \multicolumn{2}{|c|}{ EC } & \multicolumn{2}{|c|}{$\mathrm{Na}$} & \multicolumn{2}{|c|}{ Mg } \\
\hline & & & & $u_{k}$ & $t_{k}$ & $u_{k}$ & $t_{k}$ & $u_{k}$ & $t_{k}$ & $u_{k}$ & $t_{k}$ & $\boldsymbol{u}_{k}$ & $t_{k}$ & $u_{k}$ & $t_{k}$ \\
\hline C. neglecta & 3 & 6 & 1.68 & 3.68 & 1.39 & 7.24 & 0.77 & 18.14 & 6.98 & 297.75 & 235.62 & 10.16 & 9.44 & 3.96 & 4.15 \\
\hline C. vidua & 7 & 46 & 3.11 & 4.45 & 2.27 & 7.98 & 0.41 & 26.99 & 5.20 & 408.68 & 196.94 & 4.89 & 3.47 & 2.43 & 2.98 \\
\hline P. olivaceus & 15 & 172 & 6.63 & 5.15 & 2.23 & 7.44 & 0.57 & 17.50 & 2.98 & 296.25 & 211.68 & 11.29 & 11.33 & 4.27 & 6.52 \\
\hline P. fontinalis & 10 & 146 & 3.39 & 7.32 & 2.94 & 7.98 & 0.52 & 23.57 & 4.61 & 567.02 & 205.16 & 4.21 & 6.43 & 41.75 & 25.44 \\
\hline H. incongruens & 6 & 265 & 2.16 & 5.10 & 1.94 & 8.69 & 0.56 & 25.82 & 1.93 & 563.31 & 227.39 & 39.82 & 38.39 & 13.93 & 9.98 \\
\hline H. salina & 13 & 320 & 3.77 & 5.18 & 3.06 & 7.45 & 0.82 & 21.90 & 3.83 & 555.33 & 234.71 & 12.45 & 7.38 & 18.58 & 19.61 \\
\hline H. chevreuxi & 4 & 105 & 1.22 & 3.83 & 1.82 & 7.99 & 0.70 & 22.66 & 7.03 & 339.60 & 216.42 & 5.99 & 19.88 & 5.51 & 1.92 \\
\hline I. bradyi & 6 & 67 & 1.73 & 9.24 & 3.04 & 8.07 & 0.26 & 13.10 & 7.64 & 328.66 & 303.95 & 4.58 & 8.36 & 9.01 & 12.12 \\
\hline L. inopinata & 7 & 60 & 3.70 & 6.34 & 1.28 & 8.29 & 0.46 & 22.96 & 4.51 & 549.13 & 258.97 & 8.60 & 6.47 & 24.55 & 20.03 \\
\hline P. arcuata & 4 & 85 & 2.30 & 4.62 & 2.85 & 8.01 & 0.81 & 26.84 & 4.87 & 374.41 & 225.98 & 26.90 & 12.85 & 5.18 & 2.53 \\
\hline \multirow[t]{4}{*}{$P$. variegata } & 4 & 804 & 1.24 & 6.61 & 0.48 & 8.15 & 0.31 & 31.09 & 2.88 & 252.55 & 43.80 & 5.22 & 1.56 & 2.48 & 1.45 \\
\hline & & & Mean & 5.59 & 2.12 & 7.94 & 0.56 & 22.78 & 4.77 & 412.06 & 214.60 & 12.19 & 11.41 & 11.97 & 9.70 \\
\hline & & & Min. & 3.68 & 0.48 & 7.24 & 0.26 & 13.10 & 1.93 & 252.55 & 43.80 & 4.21 & 1.56 & 2.43 & 1.45 \\
\hline & & & Max. & 9.24 & 3.06 & 8.69 & 0.82 & 31.09 & 7.64 & 567.02 & 303.95 & 39.82 & 38.39 & 41.75 & 25.44 \\
\hline
\end{tabular}

Abbreviations: Count, numbers of species occurrence; Max, maximum numbers of individuals; N2, Hill's coefficient (measure of effective number of occurrences); $\mathrm{u}_{\mathrm{k}}$, optimum values; $\mathrm{t}_{\mathrm{k}}$, ecological tolerance values. See Tables 4 and A1 in the Appendix for the other abbreviations

Numbers of species with (17 spp.) and without (20 spp.) swimming setae on A2 were not significantly different $(P>0.05)$ between artificial (e.g., trough, reservoir, canal etc.) and natural (e.g., lake, spring, creek etc.) habitats (Table 3). Among the species, 13 species were commonly found in both natural and artificial habitats. Parthenogenetic populations herein were encountered from all of the habitat types, while only five sexual populations (Candona neglecta, C. weltneri, N. monacha, $P$. olivaceus and $P$. fontinalis) were obtained from four natural habitats (spring water, pool, ditch, waterfall), and one artificial habitat (trough). A total of 17 species were represented with parthenogenetic populations but bisexual populations of two ( $P$. olivaceus and $P$. fontinalis) of them were also reported in artificial habitats. 12 of 17 species carried swimming setae when five species had reduced setae. All of the obtained specimens of Potamocypris spp. have long swimming setae and three of them ( $P$. producta, $P$. unicaudata and $P$. villosa) were reported only from the artificial habitats (troughs) with an accompanying swimming species (Heterocypris barbara). In contrast, 4 sexual and 17 parthenogenetic species were encountered in natural habitats. Among them, 11 and 9 species were with and without swimming setae, respectively. The species $C$. neglecta, $C$. weltneri, $C$. torosa, and $P$. zenkeri are nonswimmers while $I$. decipiens, $N$. monacho and $T$. leavis are known as swimmers established solely in natural habitats (Table 3). 
Table 3. Species occurrences based on their swimming ability and types of reproduction in artificial and natural habitats. Note that sexual and parthenogenetic populations of $P$. olivaceus, also parthenogenetic populations of $P$. fontinalis were found in artificial and natural habitats. On the other hand, sexual population of $P$. fontinalis was found in only artificial habitats. This situation was taken into consideration for total numbers of species

\begin{tabular}{c|c|c|c|c}
\hline & & $\begin{array}{c}\text { Artificial } \\
\text { habitat }\end{array}$ & $\begin{array}{c}\text { Natural } \\
\text { habitat }\end{array}$ & Total \\
\hline \multirow{2}{*}{ Sexual species } & Without swimming setae & 2 & 3 & 4 \\
& With swimming setae & - & 1 & 1 \\
\hline \multirow{2}{*}{ Parthenogenetic species } & Without swimming setae & 5 & 7 & 7 \\
& With swimming setae & 12 & 10 & 14 \\
\hline \multirow{3}{*}{} & Numbers of species & 17 & 20 & 24 \\
& Numbers of individuals & 2388 & 2081 & 4469 \\
\hline
\end{tabular}

According to Shannon-Wiener index results, among the habitat types, troughs were shown as the richest habitats with regards to species diversity (up to $14 \mathrm{spp}$.) (Table 4) and numbers of individuals (2147 of 4469 ind.). On the other hand, numbers of species per site (ca. 0.54) were almost the lowest in troughs in comparison to the other habitats. In addition, although the number of troughs (26) was significantly higher than the creeks (12) and ponds (9), Shannon-Wiener ( $\left.H^{\prime}\right)$ values for troughs $\left(H^{\prime}=2.34\right)$, creeks $\left(\mathrm{H}^{\prime}=2.33\right)$ and ponds $\left(\mathrm{H}^{\prime}=2.11\right)$ were very close to each other $($ Table 4$) . \mathrm{H}^{\prime}$ values of the other habitats were relatively low and close to or less than 1.5 degree, which implies to be poor in diversity.

Although sexual populations of $P$. olivaceus and $P$. fontinalis are less-known in the literature, sexual population of them were found herein from a trough (Site 37) but individual populations of both species with different reproductive modes were also found from other habitats (Table 5). The dominance of females against males (femalebiased sex ratio) was especially remarkable at low altitudes (Sites 15, 16, 33) while the ratio was almost equal at medium altitudes (Table 5).

\section{Discussion}

Along with the 28 ostracod taxa herein, the number of recent freshwater ostracod species of the Muğla province is now increased to 49 with the addition of previous reports (e.g. Gülen, 1985a; Aygen et al., 2004).

According to CCA and Spearman correlation analyses, the water temperature was the most effective factor on species occurrences and composition (Fig. 2). Especially, the ecological tolerance and optimum values of the commonly occurring species were found relatively higher than the other species. For example, common occurrences of $P$. olivaceus in many aquatic habitats (with 15 independent occurrences) agree with the literature (Meisch, 2000) that pinpointed the relatively high ecological tolerance levels of this species for many ecological variables. Also, Külköylüoğlu and Y1lmaz (2006) suggested that $P$. olivaceus have a broader geographical distribution as long as habitat conditions are suitable.

In the present study, there was no statistical difference between the population density or the number of species in the natural or the artificial habitats. On the other hand, while the number of the swimming and non-swimming species were close to each other in the natural habitats with 11 and $10 \mathrm{spp}$., respectively, the number of the 
swimming species (12 spp.) was higher than the numbers of non-swimmers (7 spp.) in the artificial habitats (Table 3). Species in such habitats can alter their location faster in active way (using swimming setae) than passive one due to unpredictable ecological conditions of artificial habitats (e.g., troughs). Thus, such ability of active movement may increase their survival chances by finding new location. Along with these movement abilities, the importance of ecological fitting abilities of species and habitat suitability should not be ignored for the survival success of species in different niches or wider range of habitats.

Table 4. Species diversity and population density of different habitat types

\begin{tabular}{|c|c|c|c|c|c|c|c|c|c|c|}
\hline Habitat type & N.St & N.Sp & N.Ind & Spp/St & Obs & Obs/St & $\operatorname{Var} \mathbf{H}^{\prime}$ & Exp H' & $\mathbf{H}^{\prime}$ & Species \\
\hline Canal & 4 & 5 & 168 & 1.25 & 3 & 0.75 & 0.08 & 5.00 & 1.61 & $P O, H S, H C, I B, L I$ \\
\hline Creek & 12 & 11 & 254 & 0.92 & 9 & 0.75 & 0.02 & 10.31 & 2.33 & $\begin{array}{c}C T, P O, P F, H I, H S, I B, L I, \\
\text { PZ, Asp*, Cysp, Psp }\end{array}$ \\
\hline Ditch & 2 & 3 & 11 & 1.50 & 2 & 1.00 & 0.11 & 3.00 & 1.10 & $C V, H C, N M$ \\
\hline Lake & 2 & 1 & 7 & 0.50 & 2 & 1.00 & 0.00 & 1.00 & 0.00 & $C T$ \\
\hline Pond & 9 & 9 & 1154 & 1.00 & 5 & 0.56 & 0.03 & 8.22 & 2.11 & $\begin{array}{c}C N, C V, H C, I G, I H, P A, P V, \\
T L, C s p \\
\end{array}$ \\
\hline Pool & 1 & 1 & 6 & 1.00 & 1 & 1.00 & 0.00 & 1.00 & 0.00 & $C N$ \\
\hline Reservoir & 3 & 6 & 73 & 2.00 & 3 & 1.00 & 0.07 & 5.74 & 1.75 & $C V, P F, I H, L I, C s p, P s p$ \\
\hline Spring water & 6 & 6 & 578 & 1.00 & 6 & 1.00 & 0.05 & 4.87 & 1.58 & $C N, P O, P F, H S, H B r, I B$ \\
\hline Stream & 2 & 3 & 19 & 1.50 & 1 & 0.05 & 0.11 & 3.00 & 1.10 & $I B, I D, L I$ \\
\hline Waterfall & 1 & 4 & 52 & 4.00 & 1 & 1.00 & 0.09 & 4.00 & 1.39 & $C W, P O, P F, I B$ \\
\hline Trough & 26 & 14 & 2147 & 0.54 & 22 & 0.85 & 0.02 & 10.37 & 2.34 & $\begin{array}{l}C V, P O, P F, H B, H I, H S, H C, \\
H B r, I G, P A, P P, P U, P V, P v i\end{array}$ \\
\hline $\begin{array}{l}\text { All sample } \\
\text { index }\end{array}$ & 28 & & & & & & & & 2.97 & \\
\hline $\begin{array}{c}\text { Jackknife } \\
\text { standard error }\end{array}$ & 4.05 & & & & & & & & 0.14 & \\
\hline
\end{tabular}

Abbreviations: N.St., number of site; N.Sp., number of species; N.Ind., number of individual; Spp/st, ratio of number of species per site; Obs., number of observation; Obs/St, ratio of number of observations per site; H', Shannon-Wiener Index value; Var. H', variance H'; Exp H', expected value of H'. Species codes: $C N$ : Candona neglecta, $C W$ : Candona weltneri, CT: Cyprideis torosa, CV: Cypridopsis vidua, PO: Psychrodromus olivaceus, PF: Psychrodromus fontinalis, HB: Heterocypris barbara, HI: Heterocypris incongruens, HS: Hetercypris salina, HC: Herpetocypris chevreuxi, HBr: Herpetocypris brevicaudata, IB: Ilyocypris bradyi, ID: Ilyocypris decipiens, IG: Ilyocypris gibba, IH: Ilyocypris hartmanni, LI: Limnoctyhere inopinata, NM: Notodromas monacha, PA: Potamocypris arcuata, PP: Potamocypris producta, PU: Potamocypris unicaudata, PV: Potamocypris variegata, PVi: Potamocypris villosa, PZ: Prionocypris zenkeri, TL: Trajancypris leavis, Cysp: Cypris sp., Psp: Pseudocandona sp., Csp: Cypridopsis sp., Asp: Aurila sp. *brackish water taxon

Among habitats, troughs are generally located in/near villages to provide water for drinking, cleaning and/or irrigation purposes and they are used as microhabitats by ostracods (Külköylüoğlu et al., 2013). Such kind of artificial habitats (e.g., troughs) can open new possibilities for other species, although the establishment of troughs from natural sources can cause irreversible changes in species diversity and habitats. Because, waters of troughs come from underground sources, springs and/or surface waters, and these connections with those of natural habitats may influence species diversity (Külköylüoğlu et al., 2013). Except these water connections, different transportation vectors (e.g., air, insect, fish, birds, humans) may enrich species diversity 
since ostracods can be distributed passively between different aquatic habitats by such kind of vectors (Mezquita et al., 1999). All of these explain the high Shannon-Wiener index value of troughs among habitats.

Table 5. The distribution of sexual and parthenogenetic populations of $P$. olivaceus and $P$. fontinalis at different habitats from $14 \mathrm{~m}$ to $1093 \mathrm{~m}$ of altitude

\begin{tabular}{|c|c|c|c|c|c|c|c|c|c|c|c|c|}
\hline \multicolumn{3}{|c|}{ Species } & \multicolumn{2}{|c|}{$\begin{array}{c}\text { Psychrodromus } \\
\text { olivaceus }\end{array}$} & \multicolumn{2}{|c|}{$\begin{array}{l}\text { Psychrodromus } \\
\text { fontinalis }\end{array}$} & \multicolumn{2}{|c|}{$\begin{array}{l}\text { Candona } \\
\text { neglecta }\end{array}$} & \multicolumn{2}{|c|}{$\begin{array}{c}\text { Candona } \\
\text { weltneri }\end{array}$} & \multicolumn{2}{|c|}{$\begin{array}{c}\text { Notodromas } \\
\text { monacho }\end{array}$} \\
\hline St. No. & Alt. (m) & Habitat type & $q$ & $\hat{0}$ & 9 & $\hat{0}$ & $q$ & 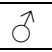 & $q$ & 0 & 우 & $\hat{0}$ \\
\hline 62 & 14 & Creek & 6 & & & & & & & & & \\
\hline 65 & 114 & Creek & 35 & & 15 & & & & & & & \\
\hline 63 & 136 & Trough & 5 & & & & & & & & & \\
\hline 17 & 294 & Spring water & 3 & & 6 & & & & & & & \\
\hline 66 & 296 & Canal & 126 & & & & & & & & & \\
\hline 39 & 351 & Spring water & 36 & & 14 & & & & & & & \\
\hline 33 & 362 & Spring water & 80 & 15 & & & 1 & & & & & \\
\hline 19 & 484 & Reservoir & & & 3 & & & & & & & \\
\hline 20 & 490 & Trough & 1 & & & & & & & & & \\
\hline 47 & 504 & Creek & & & 2 & & & & & & & \\
\hline 49 & 540 & Trough & & & 146 & & & & & & & \\
\hline 35 & 609 & Ditch & & & & & & & & & 3 & 4 \\
\hline 18 & 656 & Trough & 85 & & & & & & & & & \\
\hline 68 & 656 & Pond & 30 & & 14 & & & & 5 & 2 & & \\
\hline 15 & 669 & Spring water & 152 & 20 & & & & & & & & \\
\hline 16 & 669 & Spring water & 146 & 10 & & & & & & & & \\
\hline 36 & 699 & Pool & & & & & 3 & 3 & & & & \\
\hline 50 & 769 & Trough & & & 124 & & & & & & & \\
\hline 46 & 799 & Trough & 3 & & 7 & & & & & & & \\
\hline 38 & 808 & Trough & 1 & & & & & & & & & \\
\hline 42 & 839 & Pond & & & & & 1 & & & & & \\
\hline 37 & 1093 & Trough & 12 & 6 & 21 & 8 & & & & & & \\
\hline & & Total & 721 & 51 & 352 & 8 & 5 & 3 & 5 & 2 & 3 & 4 \\
\hline
\end{tabular}

Potamocypris producta was commonly found in Africa (see e.g., Sars, 1924; Martens, 1984) but it was also reported from Europe (Macedonia, Petkovski, 1964), Japan (Okubo, 1976), and Turkey. Males of the species were only reported from South Africa by Sars (1924). 48 female individuals of $P$. producta in a trough along with $P$. olivaceus and $H$. Barbara were found. This record of $P$. producta herein makes an important contribution to the distribution and ecological preferences of species. This indicates that the species can also be found in artificial habitats.

The occurrence of parthenogenetic and sexual populations of $P$. olivaceus and $P$. fontinalis in troughs (Table 5) contribute to the knowledge of the habitat preferences of these species with different reproduction modes. This situation probably signals to a passive dispersal of them by subaquatic/nearby springs or underground waters, since these two species are known to prefer spring waters, flowing waters and pond fed by springs (Meisch, 2000). Fox (1965) claimed that males of $P$. fontinalis were found in northern Italy but later, Baltanás et al. (1993) stated that these specimens belong to another species, $P$. betharrami, collected from a subterranean stream in the Cave of Betharram (France). Sexual populations of $P$. fontinalis were described for the first time 
in Macedonia by Petkovski and Meisch (1995). Until now, there is no any report of the sexual populations of these species from Turkey. Therefore, the sexual population of $P$. fontinalis herein is the first report from Turkey. However, males of P. olivaceus are already known from different countries of Europe (Petkovski, 1959, 1966; Järvekülg, 1959; Petkovski and Meisch, 1995). In Turkey, the male of P. olivaceus was found for the first time by Gülen (1985b) in the Lake Karamik (Afyon) and followed by other studies (Külköylüoğlu and Yılmaz, 2006; Rasouli et al., 2014; Külköylüoğlu et al., 2015; the present study).

Among these records, similar distribution patterns of $P$. producta and $P$. fontinalis were recorded from Macedonia and Turkey, and this may be explained with different passive dispersion ways. For instance, it is well known that Anatolia is an important migration route and works as a bridge between the Balkans and Africa for some migratory birds (Deinet et al., 2013). Ostracods can attach to the external surface of the birds, and so they are transported passively among the different geographic regions. Additionally, the record of $P$. producta from Japan is an interesting finding and might signal a human-mediated dispersal. Considering that the success of the species transported is related to the habitat suitability, and the ecological and biological features of the species, these records show the fitting ability under suitable environmental conditions of these two species.

Although troughs have relatively high ostracod diversity, the numbers of species per trough is not the highest among habitats (Table 4). Comparing to other sites, this situation may be explained with more samplings from these artificial habitats. However, another interesting point here is that although the number of individuals in troughs was prominently high, most of the individuals (1111 of 2147) collected from troughs belonged to two well-known cosmopolitan species (H. incongruens and H. salina). Moreover, finding at least two other species (e.g., P. olivaceus, Potamocypris unicaudata) with high densities in these habitats suggests that such artificial habitats can provide some chance of survival mainly for species with relatively high ecological tolerance ranges. Actually, troughs are routinely cleaned out and emptied by local people. Eventually, such process can cause a huge impact on the populations. In such case, ostracods may leave their desiccation resistant eggs until troughs are filled by water again. It means that the species with their cosmopolitan features as well as their adaptive values to harsh environmental conditions can easily colonize in the troughs. If troughs are accepted as newly development habitat after habitat degradation, in the case of recolonization, high ostracod richness and strong dominance of cosmopolitan species in troughs are inevitable. Therefore, this situation indicates the "primer succession" of species with high ecological tolerance levels as transitional and/or opportunistic populations. Additionally, most of the species found from troughs were parthenogens, even though some species were represented with sexual populations in a trough. A similar case observed in a newly developed spring in Turkey (Külköylüoğlu, 2009) supports this previous statement. The dominance of the parthenogens in following colonization may be the sign of the transition to stability or predictability in the environmental conditions, because it is known that if environmental deterioration continues as a result of stochastic and drastic changes, such kind of habitats can be established by sexual populations (Hewitt, 1999; Horne and Martens, 1999). Thus, it can be argued that the different reproduction modes of species can be effective as well as their relatively wide ecological tolerance levels for the initial colonization of the habitats. 
As seen in Table 5, sexual populations of $P$. olivaceus and $P$. fontinalis co-occurred in a trough (St. 37) and there is a difference in the sex ratio of the individuals of both species. Generally, one of the reasons of female-biased sex ratio can be explained by the presence of the females of species with both reproductive modes from the same sampling site. On the other hand, although it is not the scope of this study, some genetic factors can play a role such as the greater longevity of females that lead to the skewed sex ratio in the population (Butlin et al., 1998). Thus, the possible reasons of the skewed sex ratio can be better understood by means of genetic data to determine the proportion of the fully sexual and parthenogenetic females.

In contrast to Gülen (1985b) who reported the sex ratio of $P$. olivaceus as about $1 / 2$ favoring males (16 females and 33 males), the ratio in our study was almost about 1/8 favoring the females. The dominance of females against males (female-biased sex ratio) was especially remarkable at low altitudes (e.g., cf. stations 15, 16, 33) where the population densities were high. However, both the numbers of female and male became close to each other, and population densities were low at medium altitude (st. 37, $1093 \mathrm{~m}$ ). In addition, the first record of the sexual forms of $P$. olivaceus was given by Petkovski (1959) from the moderately medium altitudes $(1300 \mathrm{~m})$ to high altitudes (ca. $2200 \mathrm{~m}$ ) favoring the females. In the present study, a sexual population of P. olivaceus was found from two spring waters and one trough located at different altitudes that put into the previously known altitudinal ranges. Unlike $P$. olivaceus, the sexual populations of $P$. fontinalis were only found from a trough at $1093 \mathrm{~m}$ in Muğla. Males of $P$. fontinalis were also known from a small mountain spring water at $1600 \mathrm{~m}$ a.s.l (Petkovski and Meisch, 1995). The ranges of altitude (312-1262 m, Külköylüoğlu et al., (2012b) where species occur in literature reinforce the statement of Külköylüoğlu et al. (2012a) as parthenogenetic populations of $P$. fontinalis had the highest tolerance values for altitude. Similarly, parthenogenetic populations of $P$. fontinalis were found at various altitudes ranging from $114 \mathrm{~m}$ to $1093 \mathrm{~m}$ a.s.l. in the present study.

Parthenogenetic populations of the species were found from sea level to $1093 \mathrm{~m}$, while sexual populations were obtained in a limited number of habitats located between 327 and $1093 \mathrm{~m}$ a.s.l. Külköylüoğlu et al. (2012b) showed no relationship between occurrence of sexual and parthenogenetic forms at different altitudes, although Peck et al. (1998) suggested that population densities of parthenogens exhibited the tendency to occur in northern areas at high altitudes.

According to the hypotheses of the distributional patterns of ostracods in terms of reproduction modes, both circum-Mediterranean shelters staying after the Pleistocene glaciation, and the fluctuating environmental conditions of the early Holocene, persisted some sexual populations in southern regions (i.e., post glacial invasion/re-colonization hypothesis). The following Holocene climatic stability provided more common dispersion and increase of frequencies of the parthenogens (Holocene stability hypothesis) (Horne and Martens, 1999). Similarly (but not in the same way), during this glaciation period, Anatolia played a critical role for the survival of both sexual and parthenogens providing opportunity to recolonize species in the other regions (Gülen, 1985a; Hewitt, 1999; Külköylüoğlu et al., 2012b). Additionally, as stated above, since Anatolia is an important route for the migration of birds, the ostracods species can be transported via passive dispersion from different regions to Anatolia. Then, other factors, such as different climatic conditions, latitudes in Anatolia, allow the colonization of the species in new locations. Thus, finding the males of $P$. fontinalis 
along with $P$. olivaceus supports the idea that "there are so many sexual populations in Turkey" (Külköylüoğlu et al., 2012b).

\section{Conclusion}

Overall, along with ecological preferences and tolerance levels of the species, if it is created the distributional patterns of ostracods according to their reproductive modes, ostracods can be used as an informative marker for monitoring environmental changes for the neo-studies. On the other hand, to know (i) how species diversity is affected when species faced with changes in habitat degradation, (ii) which species are the first members of the new colonization or (iii) that there is any remarkable alteration favoring the parthenogens or sexual in time after the dramatic environmental changes provides useful information for invisible environmental shifts (e.g. volcanic eruptions, drought) in the palaeo-studies. Due to short sampling time, our results, however, cannot be generalized at the moment but they support the idea that parthenogenetic species (and populations as well) clearly show a much wider geographical distribution than their sexual counterparts. Therefore, different factors and/or combination of them that affect this distribution (ecological, historical, and biological) should be investigated comprehensively.

Acknowledgements. The work was supported by the Scientific and Technological Research Council of Turkey (TUBITAK) (Project no: 2130172). We thank the anonymous reviewers for their comments and suggestions on our manuscript.

\section{REFERENCES}

[1] Aygen, C., Balık, S., Ustaoğlu, R. M. (2004): Two new records for the non-marine ostracod fauna of Turkey: Humphcypris subterranea (Hartmann, 1964) and Herpetocypris brevicaudata Kaufmann, 1900. - Zoology in the Middle East 31(1): 77-82.

[2] Baltanás, A., Danielopol, D. L., Roca, J. R., Marmonier, P. (1993): Psychodromus betharrami n. sp. (Crustacea, Ostracoda): morphology, ecology and biogeography. - Zoologicher Anzeiger 231(1-2): 39-57.

[3] Broodbaker, N., Danielopol, D. L. (1982): The Chaetotaxy of Cypridacea (Crustacea, Ostracoda) limbs: proposals for a descriptive model. - Bijdragen tot de Dierkunde 52(2): 103120.

[4] Butlin, R., Schön, I., Martens, K. (1998): Asexual reproduction in nonmarine ostracods. Journal of Heredity 81(5): 473-480.

[5] Carbonel, P., Colin, J. P., Danielopol, D. L., Löffler, H., Neustrueva, I. (1988): Paleoecology of limnic ostracodes: a review of some major topics. - Palaeogeography, Palaeoclimatology, Palaeoecology 62(1-4): 413-461.

[6] Cohen, A. C., Morin, J. G. (1990): Patterns of Reproduction in Ostracodes: a review. Journal of Crustacean Biology 10(2): 184-211.

[7] Cohuo, S., Macario, L., Pérez, L., Naumann, K., Schwalb, A. (2015): Effects of Altitudinal Gradients in Neotropical Ostracod Species Composition and Distribution: An Example from North-Central Guatemala. - In: Perrier, V., Meidla, T. (eds.) Abstracts, 8th European Ostracodologists Meeting, Tartu, Estonia, 22-30 July 2015.

[8] Deinet, S., Ieronymidou, C., McRae, L., Bureld, I. J., Foppen, R. P., Collen, B., Böhm, M. (2013): Wildlife Comeback in Europe: The Recovery of Selected Mammal and Bird Species. 
Final Report to Rewilding Europe by ZSL, BirdLife International and the European Bird Census Council. ZSL, London.

[9] Dudgeon, D., Arthington, A. H., Gessner, M. O., Kawabata, Z. I., Knowler, D. J., Lévêque, C., Naiman, R. J., Prieur-Richard, A. H., Soto, D., Staissny, M. L. J., Sullivan, C. A. (2006): Freshwater biodiversity: importance, threats, status and conservation challenges. - Biological Reviews 81(2): 163-182.

[10] Finlayson, C. M., Davis, J. A., Gell, P. A., Kingsford, R. T., Parton, K. A. (2013): The status of wetlands and the predicted effects of global climate change: the situation in Australia. Aquatic Sciences 75(1): 73-93.

[11] Fox, H. M. (1965): Discovery of a male Ilyodromus fontinalis (Wolf) (Crustacea, Ostracoda). - Memorie dell'Istituto Italiano di Idrobiologia 18: 197-201.

[12] Gonzalez Mozo, M. E., Martens, K., Baltanás, A. (1996): A Taxonomic Revision of Europan Herpetocypris Brady and Norman, 1889 (Crustacea, Ostracoda). - Biologie 66: 93-132.

[13] Gülen, D. (1985a): The species and distribution of the group of Podocopa (OstracodaCrustacea) in freshwaters of western Anatolia. - İstanbul Üniversitesi Fen Fakültesi Mecmuasi 50: 65-80.

[14] Gülen, D. (1985b): Bisexual ostracoda (Crustacea) populations in Anatolia. - İstanbul Üniversitesi Fen Fakültesi Mecmuas1 50: 81-86.

[15] Heino, J., Tolonen, K. T. (2018): Ecological niche features override biological traits and taxonomic relatedness as predictors of occupancy and abundance in lake littoral macroinvertebrates. - Ecography 41(12): 2092-2103.

[16] Hewitt, G. M. (1999): Post-glacial re-colonization of European biota. - Biological Journal of the Linnean Society 68(1-2): 87-112.

[17] Horne, D. J., Martens, K. (1999): Geographical parthenogenesis in European non-marine ostracods (Crustacea: Ostracoda): post-glacial invasion or Holocene stability? Hydrobiologia 391: 1-7.

[18] Hurlbert, S. H. (1984): Pseudoreplication and the design of ecological field experiments. Ecological Monographs 54(2): 187-211.

[19] Järvekülg, A. (1959): The finding of a male Ilyodromus olivaceus (Brady and Norman) (Ostracoda, Cypridae). Eesti NSV Teaduste Akadeemia Toimetised. - Biologia 8: 242.

[20] Juggins, S. (2003): Software for ecological and palaeoecological data analysis and visualization, $\mathrm{C}^{2}$ User Guide. - University of Newcastle, Newcastle-Upon-Tyne.

[21] Karanovic, I. (2012): Recent Freshwater Ostracods of the World. - Springer, Heidelberg.

[22] Külköylüoğlu, O. (2004): On the usage of ostracods (Cruatacea) as bioindicator species in different aquatic habitats in the Bolu region, Turkey. - Ecological Indicators 4: 139-147.

[23] Külköylüoğlu, O. (2009): Ecological succession of freshwater Ostracoda (Crustacea) in a newly developed rheocrene spring (Bolu, Turkey). - Turkish Journal of Zoology 33(2): 115-123.

[24] Külköylüoğlu, O., Yılmaz, F. (2006): Ecological requirements of Ostracoda (Crustacea) in three types of springs in Turkey. - Limnologica-Ecology and Management of Inland Waters 36(3): 172-180.

[25] Külköylüoğlu, O., Akdemir, D., Yüce, R. (2012a): Distribution, ecological tolerance and optimum levels of freshwater Ostracoda (Crustacea) from Diyarbakır, Turkey. - Limnology 13(1): 73-80.

[26] Külköylüoğlu, O., Sarı, N., Akdemir, D., Yavuzatmaca, M., Altınbağ, C. (2012b): Distribution of sexual and asexual Ostracoda (Crustacea) from different altitudinal ranges in the Ordu region of Turkey: testing the rapoport rule. - High Altitude Medicine and Biology 13(2): 126-137.

[27] Külköylüoğlu, O., Akdemir, D., Sarı, N., Yavuzatmaca, M., Oral, C., Başak, E. (2013): Distribution and ecology of Ostracoda (Crustacea) from troughs in Turkey. - Turkish Journal of Zoology 37(3): 277-287.

[28] Külköylüoğlu, O., Akdemir, D., Yavuzatmaca, M., Y1lmaz, O. (2015): A checklist of recent non-marine Ostracoda (Crustacea) of Turkey with three new records. - Review of Hydrobiology 8(2): 77-90. 
[29] Martens, K. (1984): Annotated checklist of non-marine ostracods (Crustacea, Ostracoda) from African inland waters. - Zoologische Documentatie - N20-Koninklijk Museum voor Midden-Afrika.

[30] Martens, K., Schön, I., Meisch, C., Horne, D. J. (2008): Global diversity of ostracods (Ostracoda, Crustacea) in freshwater. - Hydrobiologia 595(1): 185-193.

[31] Mayr, E., Ashlock, P. D. (1991): Principles of Systematic Zoology. $2^{\text {nd }}$ Ed. - McGraw-Hill, New York.

[32] Meisch, C. (2000): Freshwater Ostracoda of Western and Central Europe (Süsswasserfauna von Mitteleuropa 8/3). - Spektrum Akademischer Verlag, Heidelberg.

[33] Meisch, C., Smith, R. J., Martens, K. (2019): A subjective global checklist of the extant nonmarine Ostracoda (Crustacea). - European Journal of Taxonomy 492: 1-135.

[34] Mezquita, F., Griffiths, H. I., Sanz, S., Soria, J. M., Piñón, A. (1999): Ecology and distribution of ostracods associated with flowing waters in the eastern Iberian Peninsula. Journal of Crustacean Biology 19(2): 344-354.

[35] Okubo, I. (1976): Potamocypris producta (Sars, 1924) from Japan (Ostracoda, Cyprididae). Researches on Crustacea 7: 52-56.

[36] Peck, J. R., Yearsley, J. M., Waxman, D. (1998): Explaining the geographic distributions of sexual and asexual populations. - Nature 391: 889-892.

[37] Petkovski, T. K. (1959): Beitrag zur Kenntnis der Ostracodenfauna Jugoslawiens (V). Hidrobiologi. Publications of the Hydrobiological Research Institute, Faculty of Science, University of Istanbul, Seri B 4(4): 158-165.

[38] Petkovski, T. K. (1964): Bemerkenswerte Entomostraken aus Jugoslavien. - Acta Musei Macedonici Scientiarum Naturalium 9: 147-182.

[39] Petkovski, T. K. (1966): Ostracoden aus einigen Quellen der Slowakei. - Acta Musei Macedonici Scientiarum Naturalium 10: 91-168.

[40] Petkovski, T. K., Meisch, C. (1995): Interesting freshwater Ostracoda (Crustacea) from Macedonia. - Bulletin de la Societe des Naturalistes Luxembourgeois 96: 176-183.

[41] Rasouli, H., Aygen, C., Külköylüoğlu, O. (2014): Contribution to the Freshwater Ostracoda (Crustacea) Fauna of Turkey: Distribution and Ecological Notes. - Turkish Journal of Fisheries and Aquatic Sciences 14: 11-20.

[42] Ruban, V., Lópes-Sánchez, J. F., Pardo, P., Rauret, G., Muntau, H., Quevauviller, P. (1999): Selection and evaluation of sequential extraction procedures for the determination of phosphorus forms in lake sediment. - Journal of Environmental Monitoring 1: 51-56.

[43] Sars, G. O. (1924): The freshwater Entomostraca of the Cape Province. - Annals of the South African Museum 20: 105-193.

[44] Seaby, R. M., Henderson, P. A. (2006): Species Diversity and Richness Version IV. - Pisces Conservation Ltd, Lymington.

[45] ter Braak, C. J. F. (1986): Canonical correspondence analysis: a new eigenvector technique for multivariate direct gradient analysis. - Ecology 67: 1167-1179.

[46] ter Braak, C. J. F., Šmilauer, P. (2012): Canoco Reference Manual and User's Guide: Software for Ordination, Version 5.0. - Microcomputer Power, Ithaca.

[47] Yavuzatmaca, M., Külköylüoğlu, O., Y1lmaz, O., Akdemir, D. (2017): On the relationship of ostracod species (crustacea) to shallow water ion and sediment phosphate concentration across different elevational range (Sinop, Turkey). - Turkish Journal of Fisheries and Aquatic Sciences 17(7): 1333-1346.

[48] Wagner, C. W. (1964): Ostracods as environmental indicators in recent and holocene estuarine deposits of the Netherlands. - Pubblicazioni della Stazione Zoologica di Napoli 33: 480-495.

[49] Wiens, J. J. (2011): The niche, biogeography and species interactions. - Philosophical Transactions of the Royal Society of London B: Biological Sciences 366(1576): 2336-2350.

[50] Williams, M., Siveter, D. J., Salas, M. J., Vannier, J., Popov, L. E., Pour, M. G. (2008): The earliest ostracods: The geological evidence. - Senckenbergiana Lethaea 88(1): 11-21. 


\section{APPENDIX}

Table A1. Minimum-maximum values of the geographical data and physicochemical variables from 11 different aquatic habitat types with station numbers in Muğla province

\begin{tabular}{|c|c|c|c|c|c|c|c|c|c|}
\hline & & Ta & Atm & Moi & Wind & Alt & pH & DO & $\mathbf{S}$ \\
\hline \multirow{4}{*}{ Canal } & Min & 21.700 & 727.300 & 34.700 & 0.000 & 17.000 & 8.220 & 3.260 & 42.400 \\
\hline & Max & 33.800 & 754.800 & 63.600 & 6.400 & 296.000 & 8.520 & 7.360 & 83.600 \\
\hline & Mean & 30.275 & 745.500 & 45.200 & 3.075 & 110.500 & 8.353 & 5.538 & 63.025 \\
\hline & St dev & 3.139 & 26.103 & 11.020 & 4.506 & 308.349 & 0.638 & 2.352 & 22.683 \\
\hline \multirow{4}{*}{ Creek } & Min & 23.600 & 702.600 & 27.500 & 0.000 & 5.000 & 7.090 & 2.000 & 22.500 \\
\hline & Max & 33.200 & 757.400 & 67.400 & 7.700 & 790.000 & 8.820 & 8.060 & 83.800 \\
\hline & Mean & 30.275 & 735.175 & 46.917 & 2.783 & 272.750 & 7.893 & 4.761 & 56.308 \\
\hline & St dev & 2.800 & 25.877 & 11.099 & 4.413 & 308.862 & 0.639 & 2.351 & 22.918 \\
\hline \multirow{4}{*}{ Ditch } & Min & 29.500 & 705.300 & 38.700 & 2.200 & 19.000 & 8.150 & 3.020 & 37.500 \\
\hline & $\operatorname{Max}$ & 31.500 & 755.600 & 49.200 & 4.200 & 609.000 & 8.330 & 6.630 & 86.000 \\
\hline & Mean & 30.500 & 730.450 & 43.950 & 3.200 & 314.000 & 8.240 & 4.825 & 61.750 \\
\hline & St dev & 2.797 & 26.454 & 10.740 & 4.594 & 310.429 & 0.652 & 2.406 & 23.301 \\
\hline \multirow{4}{*}{ Lake } & Min & 28.500 & 752.900 & 44.500 & 3.200 & 17.000 & 8.690 & 4.840 & 65.900 \\
\hline & Max & 32.800 & 759.100 & 52.600 & 9.500 & 17.000 & 8.760 & 4.870 & 68.500 \\
\hline & Mean & 30.650 & 756.000 & 48.550 & 6.350 & 17.000 & 8.725 & 4.855 & 67.200 \\
\hline & St dev & 2.816 & 26.636 & 10.782 & 4.630 & 311.697 & 0.662 & 2.386 & 22.953 \\
\hline \multirow{4}{*}{ Pond } & Min & 23.100 & 685.000 & 26.300 & 0.000 & 40.000 & 7.810 & 2.140 & 5.980 \\
\hline & Max & 33.900 & 754.000 & 55.900 & 15.700 & 839.000 & 9.810 & 7.420 & 97.600 \\
\hline & Mean & 30.122 & 719.722 & 41.678 & 5.556 & 434.000 & 8.772 & 5.984 & 69.531 \\
\hline & St dev & 2.884 & 26.536 & 10.812 & 4.611 & 310.229 & 0.700 & 2.335 & 24.465 \\
\hline Pool* & Mean & 29.200 & 697.500 & 35.400 & 8.900 & 699.000 & 7.080 & 3.300 & 33.400 \\
\hline \multirow{4}{*}{ Spring water } & Min & 27.700 & 701.000 & 28.800 & 0.000 & 294.000 & 6.450 & 3.300 & 37.500 \\
\hline & Max & 33.500 & 773.500 & 49.100 & 4.800 & 669.000 & 8.040 & 10.340 & 93.700 \\
\hline & Mean & 32.100 & 722.600 & 35.900 & 3.533 & 493.500 & 7.313 & 5.643 & 57.150 \\
\hline & St dev & 2.808 & 26.412 & 10.675 & 4.489 & 301.974 & 0.677 & 2.428 & 23.166 \\
\hline \multirow{4}{*}{ Stream } & Min & 30.900 & 750.100 & 47.500 & 2.700 & 0.000 & 8.390 & 5.120 & 59.000 \\
\hline & Max & 32.100 & 751.700 & 51.800 & 3.900 & 43.000 & 8.390 & 5.360 & 60.400 \\
\hline & Mean & 31.500 & 750.900 & 49.650 & 3.300 & 21.500 & 8.390 & 5.240 & 59.700 \\
\hline & St dev & 2.798 & 26.472 & 10.788 & 4.591 & 313.260 & 0.654 & 2.384 & 22.919 \\
\hline \multirow{4}{*}{ Reservoir } & Min & 22.200 & 708.800 & 32.400 & 0.000 & 57.000 & 8.320 & 2.500 & 29.700 \\
\hline & Max & 32.600 & 752.400 & 55.400 & 7.500 & 574.000 & 9.250 & 5.750 & 75.400 \\
\hline & Mean & 28.733 & 726.533 & 45.937 & 4.267 & 371.667 & 8.657 & 4.307 & 54.500 \\
\hline & St dev & 2.961 & 26.189 & 10.849 & 4.600 & 307.379 & 0.665 & 2.394 & 23.120 \\
\hline \multirow{4}{*}{ Trough } & Min & 26.000 & 665.700 & 23.400 & 1.400 & 11.000 & 6.490 & 2.450 & 29.000 \\
\hline & Max & 35.300 & 758.600 & 64.400 & 34.000 & 1093.000 & 8.980 & 14.450 & 112.700 \\
\hline & Mean & 30.900 & 713.942 & 37.920 & 5.252 & 504.731 & 7.761 & 5.579 & 58.238 \\
\hline & St dev & 2.679 & 26.801 & 10.926 & 5.181 & 315.476 & 0.629 & 2.587 & 23.185 \\
\hline Waterfall* & Mean & 29.700 & 698.800 & 42.100 & 0.000 & 656.000 & 7.380 & 10.400 & 91.700 \\
\hline
\end{tabular}

Abbreviations: $\mathrm{Ta}$, air temperature $\left({ }^{\circ} \mathrm{C}\right)$; Atm, atmospheric pressure $(\mathrm{mmHg})$; Moi, moisture $(\%)$; Wind, $\left(\mathrm{m} \mathrm{s}^{-1}\right)$; Alt, Altitude (m); DO, dissolved oxygen $\left(\mathrm{mg} \mathrm{L}^{-1}\right)$; S, oxygen saturation (\%); Tw, water temperature $\left({ }^{\circ} \mathrm{C}\right)$; Sal, salinity (ppt); EC, electrical conductivity $\left(\mu \mathrm{S} \mathrm{cm}^{-1}\right)$; TDS, total dissolved solids $\left(\mathrm{mg} \mathrm{L}^{-1}\right) ; \mathrm{Na}^{+1}$, sodium $\left(\mathrm{mg} \mathrm{L}^{-1}\right) ; \mathrm{K}^{+1}$, potassium $\left(\mathrm{mg} \mathrm{L}^{-1}\right) ; \mathrm{Mg}^{+2}$, magnesium $\left(\mathrm{mg} \mathrm{L}^{-1}\right) ; \mathrm{Ca}^{+2}$, calcium $\left(\mathrm{mg} \mathrm{L}^{-1}\right) ; \mathrm{F}^{-1}$, fluoride $\left(\mathrm{mg} \mathrm{L}^{-1}\right)$; $\mathrm{Cl}^{-1}$, chloride $\left(\mathrm{mg} \mathrm{L}^{-1}\right) ; \mathrm{SO}_{4}^{-2}$, sulphate $\left(\mathrm{mg} \mathrm{L}^{-1}\right)$; Tot- $\mathrm{Ph}$; total phosphate $\left(\mathrm{mg} \mathrm{kg}^{-1}\right)$; In-Ph, inorganic phosphate $\left(\mathrm{mg} \mathrm{kg}^{-1}\right)$; Or-Ph; organic phosphate $\left(\mathrm{mg} \mathrm{kg}^{-1}\right)$, b.d.l. below detectable limits; * *ingle sampling 
Table A1. Continuation

\begin{tabular}{|c|c|c|c|c|c|c|c|c|c|}
\hline & & Tw & Sal & EC & TDS & $\mathrm{Na}^{+1}$ & $\mathrm{~K}^{+1}$ & $\mathbf{M g}^{+2}$ & $\mathrm{Ca}^{+2}$ \\
\hline \multirow{4}{*}{ Canal } & Min & 16.900 & 0.030 & 271.400 & 0.209 & 2.195 & 0.313 & 6.913 & 10.884 \\
\hline & Max & 28.900 & 0.380 & 736.000 & 0.410 & 18.152 & 3.898 & 40.088 & 93.513 \\
\hline & Mean & 22.450 & 0.203 & 538.350 & 0.319 & 7.542 & 1.671 & 17.153 & 52.465 \\
\hline & St dev & 5.261 & 8.701 & 247.021 & 8.113 & 67.140 & 22.478 & 30.256 & 50.092 \\
\hline \multirow{4}{*}{ Creek } & Min & 16.300 & 0.060 & 148.600 & 0.089 & 0.378 & 0.409 & 1.444 & 0.487 \\
\hline & Max & 32.200 & 73.180 & 1150.860 & 65.780 & 35.002 & 113.541 & 195.433 & 237.959 \\
\hline & Mean & 22.008 & 7.789 & 593.498 & 6.931 & 8.595 & 18.062 & 49.252 & 80.255 \\
\hline & St dev & 5.243 & 11.696 & 265.480 & 10.931 & 66.260 & 25.952 & 37.440 & 55.475 \\
\hline \multirow{4}{*}{ Ditch } & Min & 20.100 & 0.090 & 62.100 & 0.131 & 9.998 & 0.656 & 1.619 & 44.557 \\
\hline & Max & 29.800 & 0.270 & 185.000 & 0.364 & 34.042 & 17.408 & 9.395 & 72.609 \\
\hline & Mean & 24.950 & 0.180 & 123.550 & 0.248 & 22.020 & 9.032 & 5.507 & 58.583 \\
\hline & St dev & 5.312 & 9.006 & 252.891 & 8.360 & 69.616 & 23.324 & 31.175 & 50.961 \\
\hline \multirow{4}{*}{ Lake } & Min & 29.600 & 2.230 & 254.510 & 2.756 & 554.518 & 18.293 & 50.098 & 29.502 \\
\hline & Max & 30.300 & 14.070 & 466.900 & 15.210 & 554.518 & 140.824 & 58.081 & 200.468 \\
\hline & Mean & 29.950 & 8.150 & 360.705 & 8.983 & 554.518 & 79.558 & 54.090 & 114.985 \\
\hline & St dev & 5.351 & 9.121 & 248.412 & 8.526 & 97.051 & 28.672 & 31.566 & 54.076 \\
\hline \multirow{4}{*}{ Pond } & Min & 23.600 & 0.100 & 83.700 & 0.145 & 3.252 & 0.361 & 1.207 & 12.546 \\
\hline & Max & 34.100 & 0.700 & 399.300 & 0.910 & 34.068 & 19.395 & 20.041 & 238.423 \\
\hline & Mean & 29.211 & 0.201 & 254.167 & 0.271 & 11.062 & 7.652 & 7.854 & 49.126 \\
\hline & St dev & 5.416 & 8.588 & 244.248 & 7.942 & 66.192 & 22.158 & 29.928 & 53.863 \\
\hline Pool* & Mean & 16.400 & 0.140 & 0.184 & 236.300 & 8.507 & 0.329 & 3.291 & b.d.1 \\
\hline \multirow{4}{*}{ Spring water } & Min & 10.300 & 0.090 & 165.000 & 0.133 & 2.067 & 0.587 & 1.068 & 4.722 \\
\hline & Max & 21.900 & 0.410 & 694.000 & 0.533 & 29.259 & 4.009 & 10.727 & 46.601 \\
\hline & Mean & 16.683 & 0.198 & 345.750 & 0.267 & 19.072 & 1.757 & 4.704 & 25.391 \\
\hline & St dev & 5.525 & 8.759 & 249.534 & 8.113 & 68.557 & 22.962 & 30.852 & 50.758 \\
\hline \multirow{4}{*}{ Stream } & Min & 21.200 & 0.240 & 481.300 & 0.329 & 5.687 & 0.424 & 14.705 & 37.110 \\
\hline & Max & 22.400 & 0.300 & 564.000 & 0.397 & 5.935 & 0.980 & 30.134 & 37.993 \\
\hline & Mean & 21.800 & 0.270 & 522.650 & 0.363 & 5.811 & 0.702 & 22.419 & 37.551 \\
\hline & St dev & 5.252 & 9.005 & 248.131 & 8.360 & 69.641 & 23.312 & 31.080 & 50.964 \\
\hline \multirow{4}{*}{ Reservoir } & Min & 24.200 & 0.080 & 183.600 & 0.115 & 4.372 & 0.597 & 2.122 & 14.346 \\
\hline & Max & 29.700 & 0.170 & 369.100 & 0.226 & 17.790 & 2.267 & 6.258 & 46.339 \\
\hline & Mean & 27.033 & 0.137 & 298.233 & 0.170 & 11.150 & 1.558 & 3.833 & 30.153 \\
\hline & St dev & 5.272 & 8.943 & 247.683 & 8.361 & 69.086 & 23.132 & 31.029 & 50.811 \\
\hline \multirow{4}{*}{ Trough } & Min & 15.800 & 0.070 & 113.200 & 0.093 & 2.060 & 0.100 & 0.495 & 3.258 \\
\hline & Max & 32.100 & 0.650 & 913.000 & 0.845 & 108.242 & 12.396 & 68.254 & 126.984 \\
\hline & Mean & 24.054 & 0.321 & 462.350 & 0.432 & 16.715 & 2.149 & 19.002 & 48.008 \\
\hline & St dev & 4.951 & 7.811 & 250.365 & 7.217 & 60.527 & 20.357 & 29.113 & 47.648 \\
\hline Waterfall* & Mean & 9.800 & 0.140 & 0.184 & 200.800 & 1.776 & 0.336 & 5.860 & b.d.1 \\
\hline
\end{tabular}


Table A1. Continuation

\begin{tabular}{|c|c|c|c|c|c|c|c|c|}
\hline & & $F^{-1}$ & $\mathrm{Cl}^{-1}$ & $\mathrm{SO}_{4}^{-2}$ & Tot-Ph & In-Ph & Or-Ph & Station numbers \\
\hline \multirow{4}{*}{ Canal } & Min & 0.056 & 2.564 & 1.943 & 0.239 & 0.269 & 0.054 & \multirow{4}{*}{$64,66,11,56$} \\
\hline & Max & 0.140 & 38.574 & 146.011 & 0.598 & 0.737 & 0.126 & \\
\hline & Mean & 0.098 & 13.143 & 40.965 & 0.429 & 0.468 & 0.089 & \\
\hline & St dev & 0.485 & 39.211 & 110.086 & 0.267 & 0.206 & 0.066 & \\
\hline \multirow{4}{*}{ Creek } & Min & 0.026 & 0.721 & 0.324 & 0.051 & 0.096 & 0.008 & \multirow{4}{*}{$\begin{array}{c}2,5,10,21,25,31, \\
47,48,52,58,62, \\
65\end{array}$} \\
\hline & $\operatorname{Max}$ & 0.183 & 69.199 & 356.561 & 0.629 & 0.892 & 0.190 & \\
\hline & Mean & 0.110 & 14.055 & 80.035 & 0.330 & 0.282 & 0.067 & \\
\hline & St dev & 0.498 & 39.077 & 114.608 & 0.257 & 0.196 & 0.067 & \\
\hline \multirow{4}{*}{ Ditch } & Min & 0.036 & 8.526 & 13.864 & 0.648 & 0.336 & 0.356 & \multirow{4}{*}{4,35} \\
\hline & Max & 0.917 & 53.448 & 13.864 & 0.648 & 0.336 & 0.356 & \\
\hline & Mean & 0.477 & 30.987 & 13.864 & 0.648 & 0.336 & 0.356 & \\
\hline & St dev & 0.517 & 40.564 & 113.620 & 0.280 & 0.187 & 0.083 & \\
\hline \multirow{4}{*}{ Lake } & Min & 1.603 & 0.000 & 0.000 & 0.314 & 0.100 & 0.003 & \multirow{4}{*}{14,57} \\
\hline & Max & 1.603 & 0.000 & 0.000 & 0.314 & 0.171 & 0.027 & \\
\hline & Mean & 1.603 & 0.000 & 0.000 & 0.314 & 0.136 & 0.015 & \\
\hline & St dev & 0.561 & 41.012 & 114.528 & 0.276 & 0.185 & 0.069 & \\
\hline \multirow{4}{*}{ Pond } & Min & 0.060 & 4.676 & 0.491 & 0.040 & 0.001 & 0.010 & \multirow{4}{*}{$\begin{array}{c}3,7,8,12,41,42 \\
44,45,51\end{array}$} \\
\hline & Max & 0.406 & 64.564 & 799.695 & 0.612 & 0.351 & 0.214 & \\
\hline & Mean & 0.216 & 17.382 & 104.214 & 0.293 & 0.145 & 0.058 & \\
\hline & St dev & 0.472 & 38.838 & 142.439 & 0.269 & 0.185 & 0.070 & \\
\hline Pool* & Mean & 9.170 & b.d.l. & 10.291 & 3.837 & 0.160 & 0.257 & 36 \\
\hline \multirow{4}{*}{ Spring water } & Min & 0.025 & 2.605 & 2.030 & 0.170 & 0.100 & 0.019 & \multirow{4}{*}{$\begin{array}{c}15,16,17,33,39, \\
67\end{array}$} \\
\hline & Max & 2.563 & 45.591 & 70.574 & 1.720 & 0.314 & 0.064 & \\
\hline & Mean & 0.903 & 25.669 & 29.196 & 0.610 & 0.190 & 0.036 & \\
\hline & St dev & 0.632 & 39.909 & 111.036 & 0.338 & 0.184 & 0.068 & \\
\hline \multirow{4}{*}{ Stream } & Min & 0.117 & 6.171 & 9.430 & 0.153 & 0.100 & 0.006 & \multirow{4}{*}{59,61} \\
\hline & Max & 0.117 & 9.341 & 43.900 & 0.657 & 0.549 & 0.046 & \\
\hline & Mean & 0.117 & 7.756 & 26.665 & 0.405 & 0.324 & 0.026 & \\
\hline & St dev & 0.511 & 40.450 & 112.690 & 0.278 & 0.191 & 0.069 & \\
\hline \multirow{4}{*}{ Reservoir } & Min & 0.046 & 7.004 & 10.279 & 0.083 & 0.045 & 0.003 & \multirow{4}{*}{19,30} \\
\hline & Max & 0.081 & 36.789 & 28.626 & 0.197 & 0.129 & 0.063 & \\
\hline & Mean & 0.063 & 19.040 & 17.301 & 0.123 & 0.084 & 0.024 & \\
\hline & St dev & 0.505 & 40.136 & 111.841 & 0.276 & 0.187 & 0.068 & \\
\hline \multirow{4}{*}{ Trough } & Min & 0.010 & 2.330 & 1.880 & 0.213 & 0.138 & 0.040 & \multirow{4}{*}{$\begin{array}{c}1,9,13,18,20,22, \\
23,24,26,27,28, \\
29,32,34,37,38, \\
40,43,46,49,50, \\
53,54,55,60,63\end{array}$} \\
\hline & Max & 0.266 & 285.837 & 152.303 & 0.464 & 0.448 & 0.160 & \\
\hline & Mean & 0.101 & 34.196 & 24.818 & 0.345 & 0.305 & 0.064 & \\
\hline & St dev & 0.454 & 46.757 & 96.951 & 0.262 & 0.180 & 0.067 & \\
\hline Waterfall* & Mean & 45.792 & b.d.l. & 2.229 & 1.648 & 0.219 & 0.156 & 68 \\
\hline
\end{tabular}

